\title{
Brucellosis in Kosovo and Clinical Features of Brucellosis at University clinical center of Kosovo
}

\author{
Emine Qehaja Buçaj ${ }^{1}$, Edmond Puca ${ }^{2}$, Sadie Namani ${ }^{1}$, Muharem Bajrami ${ }^{1}$, Valbon Krasniqi ${ }^{1}$, \\ Lindita Ajazaj Berisha ${ }^{1}$, Xhevat Jakupi ${ }^{3}$, Bahrie Halili', Dhimiter Kraja ${ }^{1}$ \\ ${ }^{1}$ University Clinical Center of Kosovo; Clinic for Infectious Diseases in Pristina, Kosovo \\ 2 University Hospital Center, Service of Infection Diseases, Tirana, Albania \\ ${ }^{3}$ National Institute of Public health of Kosovo, Department of Microbiology
}

\begin{abstract}
Objective: Brucellosis became a remarkable disease in Kosovo. But there is not a comprehensive epidemiological study about epidemiology and clinical course of this disease from Kosovo. The aim of our study is to present demographic and clinical data of patients with brucellosis at University Clinical Center of Kosovo.

Methods: A retrospective study was performed for the patients with brucellosis treated in our clinic during years 20112012. The data about demography, history of the disease, clinical presentations, serological test, serum biochemistry and treatment were collected from hospital medical records. The diagnosis of brucellosis based on clinical and laboratory findings.

Results: This descriptive study included 47 patients, who 33 of them (70.2\%) were males. The mean age was $37.9 \pm$ 19.3 years. The route of transmission of the disease was known in 28 (59.5\%) of them. Direct contact with livestock in $22(46.8 \%)$ and ingestion of dairy products in six cases (12.7\%) were reported as the transmission route. The majority of patients (27 patients, $57.4 \%$ ) were from rural area. The main presenting symptoms were fatigue, fever and arthralgia. Osteoarticular manifestations were the common forms of localized disease. Regarding to the therapy, 45 (95.7\%) of patients were treated with streptomycin and doxycycline for the first three weeks.
\end{abstract}

Conclusion: Human brucellosis is not a common in Kosovo but there is a potential risk. Osteoarticular symptoms were the most common presentation reasons. The most effective and preferred treatment regimen was Streptomycin plus Doxycycline for the first three weeks, and Doxycycline plus Rifampicin thereafter. J Microbiol Infect Dis 2015;5(4): 147-150

Key words: Brucellosis, fever, osteoarticular involvement

\section{Kosova'da Bruselloz ve Kosova Üniversite Hastanesinde Bruselloz vakalarının klinik özellikleri}

\section{ÖZET}

Amaç: Bruselloz Kosova'da dikkat çekici bir hastalık haline geldi. Ancak Kosova'dan bu hastalığın epidemiyolojisi ve klinik seyriyle ilgili kapsamlı bir çalışma bulunmamaktadır. Bu çalışma Kosova Üniversite Merkez Hastanesinde takip edilen bruselloz hastalarının demografik ve klinik verilerini sunmayı hedef aldı.

Yöntemler: Kliniğimizde 2011-2012 yıllarında tedavi edilen bruselloz hastalarını değerlendirmek için retrospektif bir çaışma yapıldı. Demografi, hastalığın geçmişi, klinik belirtiler, serolojik testler, serum biyokimyası ve tedavi ile ilgili veriler hastane tıbbi kayıtlarından toplandı. Bruselloz tanısı klinik ve laboratuvar verilere göre konuldu.

Bulgular: Tanımlayıcı özellikteki çalışmaya 33'ü erkek $(\% 70,2)$ toplam 47 hasta katıldı. Hastaların 28'inde (\%59,5) bulaşma yolu biliniyordu. Bunlardan 22'sinde $(\% 46,8)$ doğrudan çiftlik hayvanları ile temas ve altısında $(\% 12,7)$ süt ürünlerinin tüketilmesi kaynak olarak bildirildi. Hastaların çoğu $(27$ hasta, \%57,4) kırsal bölgeden idi. Başvurudaki başlıca şikayetler yorgunluk, ateş ve eklem ağrısı idi. Osteoartiküler belirtiler lokalize olan hastalığın yaygın şekli idi. Hastaların 45'i (\%95,7) ilk üç hafta streptomisin ve doksisiklinle tedavi edildi.

Sonuç: Insan brusellozu Kosova'da yaygın olmamakla beraber potansiyel olarak risk oluşturmaktadır. Kemik ve eklem şikayetleri en yaygın başvurma nedenleri idi. En etkili ve tercih edilen tedavi rejimi streptomisin artı doksisiklin ilk üç hafatda ve daha sonra da doksisiklin artı rifampisin idi.

Anahtar kelimeler: Bruselloz, ateş, osteoartiküler tutulum

Correspondence: Edmond Puca, University Hospital Center, Service of Infection Diseases, Tirana, Albania

Email: edmond_puca@yahoo.com

Received: 03 January 2015, Accepted: 14 May 2015

Copyright (C) Journal of Microbiology and Infectious Diseases 2015, All rights reserved 


\section{INTRODUCTION}

Brucellosis is a zoonotic disease caused by Gramnegative bacteria, Brucella spp. ${ }^{1}$ Human brucellosis remains one of the most common zoonotic diseases worldwide, with more than 500,000 new cases annually. ${ }^{2-5}$ Despite being endemic in many developing countries, brucellosis remains under diagnosed and under-reported. Although it is seen widely throughout the world, it is hyperendemic in the Mediterranean Basin and Arabian Peninsula, India, Mexico, and Central and South America. ${ }^{5,6}$ The clinical features of brucellosis depend on the stage of the disease, and the organs and systems involved. ${ }^{2}$

In the absence of culture facilities, the diagnosis of brucellosis traditionally relies on serological testing with a variety of agglutination tests such as the Rose Bengal test, the serum agglutination test, and the antiglobulin or Coombs' test. On the other hand ELISA has become increasingly popular as a well-standardized assay for brucellosis.

Epidemiology of brucellosis in Kosovo was not evaluated extensively. Previous studies reported some cases but a study about brucellosis among ruminants showed that the incidence of brucellosis is quite high. ${ }^{3}$ There is not enough report about clinical features and treatment outcome of the cases with brucellosis from Kosovo.

According to the hospital records, during a seven-year period, from 2006 to 2012, 141 patients with brucellosis were treated at the Clinic of Infectious Diseases in Pristine, University Clinical Center of Kosovo, with an annual average of 20.1 cases per year. Human brucellosis is not a usually disease in Kosovo. The aim of this study was to give epidemiological and clinical picture of brucellosis in Kosovo.

\section{METHODS}

In a retrospective approach, the data from Institute of Public Health (IPH) of Kosovo has been evaluated for cases with brucellosis. The data from the medical records of the patients with brucellosis during 2011 and 2012 at the Clinic for Infectious Diseases in Pristine, University Clinical Center of Kosovo were reviewed. Information obtained from the patient records included patient history, clinical presentation, serological tests and treatment. The diagnosis of brucellosis was established by brucella titer of $>1 / 160$ in a standard tube agglutination test (STAT), enzyme-linked immunosorbent assay (ELISA IgM, IgG) and blood culture beside a com- patible clinical picture. Radiologic examinations, such as plain X-Ray, ultrasound (USG), computerized tomography (CT), magnetic resonance imaging (MRI), and echocardiography were done when needed for investigating the complications. All statistical analyses were performed with using SPSS software, version 18.0.

\section{RESULTS}

From 2009 to 2012 based on dates from Institute of Public Health of Kosovo, 279 cases were reported all over Kosovo. In total 64 cases in 2009,105 cases in 2010,65 cases in and 45 cases in 2012 were reported.

Between 2011 and 2012, 47 patients were followed at our clinic with brucellosis and 33 (70.2\%) of them were male. The patients' mean age was $37.9 \pm 19.3$ years (range 7-69 years). The majority of the patients (27 patients, $57.4 \%$ ) were from rural area. The highest incidence of patients hospitalized with brucellosis was in summer (19 cases, $40.4 \%$ ) and spring times (18 cases, $38.9 \%$ ) patients. There was a known route of infection transmission in 28 patients (59.5\%); this included direct contact with livestock in 22 cases $(46.8 \%)$ and ingestion of dairy products in six cases (12.7\%). In 19 of the patients (40.4\%) we didn't identify risk factors or transmission route. The disease was acute in 35 (74.4\%), sub-acute in seven $(14.9 \%)$ and chronic in five $(10.6 \%)$ of the patients.

According to age group the larger number of patients were between 11 and 20 years and 12 of them $(25.5 \%)$ were $>60$ years old with, followed by equal frequency of the age-group 21-30 and 31-40 years with eight $(17.0 \%)$ each.

Regarding to clinical manifestations the main presenting symptoms were fatigue, fever and arthralgia with equal frequency, anorexia, sweating, followed by back pain and restricted joint movement with equal frequency. Osteoarticular manifestations were the common forms of localized disease sacroiliitis and hip joint synovitis. Respiratory complications occurred in $10(21.2 \%)$ of patients which were diagnosed by chest X-Ray as bronchopneumonia. Neurological impairment, which occurred in nine (19.1\%) of patients, consisted of acute demyelinating polyneuropathy and peroneal radiculopathy, diagnosed with electromyoneurography (Table 1). Hydrocele developed in one patient. Lumbar punctures were performed on two of these patients, with no pathological findings. For the patients' laboratory findings, a high erythrocyte sedimentation rate 
(ESR) was recorded in $41(87.2 \%)$ of patients (>15 $\mathrm{mm} / \mathrm{h}$ ), with a high C-reactive protein value in 40 $(85.1 \%)$ patients $(>6 \mathrm{mg} / \mathrm{dl})$. We found a mild anemia $(\mathrm{Hb}<11.5 \mathrm{gr} / \mathrm{dl})$ in $11(23.4 \%)$ of patients and five $(10.6 \%)$ patients low platelet count.

Table 1. The distribution of symptoms and signs of the patients.

\begin{tabular}{lccc}
\hline $\begin{array}{l}\text { Clinical symptoms } \\
\text { and signs }\end{array}$ & $\begin{array}{c}\text { Male }(\mathbf{n}=33), \\
\text { No (\%) }\end{array}$ & $\begin{array}{c}\text { Female, } \\
\text { No }(\%)\end{array}$ & $\begin{array}{c}\text { Total, } \\
\text { No }(\%)\end{array}$ \\
\hline Fever & $27(82.6)$ & $10(71.4)$ & $37(78.7)$ \\
Sweating & $30(90.9)$ & $8(57.1)$ & $38(80.8)$ \\
Fatigue & $29(87.8)$ & $9(64.2)$ & $38(80.8)$ \\
Arthralgia & $21(63.6)$ & $12(85.7)$ & $33(70.2)$ \\
Headache & $4(12.1)$ & $2(14.2)$ & $6(12.7)$ \\
Anorexia & $26(78.8)$ & $3(21.4)$ & $29(61.7)$ \\
Splenomegaly/ia & $19(57.5)$ & $9(64.2)$ & $28(59.5)$ \\
Hepatomegaly/ia & $20(60.6)$ & $8(57.1)$ & $48(59.5)$ \\
Hepatosplenomegaly/ia & $17(51.5)$ & $6(42.8)$ & $23(48.9)$ \\
Lymphadenopathy & $5(15.1)$ & $1(7.1)$ & $6(12.7)$ \\
Back pain & $13(39.4)$ & $5(35.7)$ & $18(38.2)$ \\
Restricted joint movement & $19(57.7)$ & $4(28.5)$ & $23(48.9)$ \\
Osteoarticular manifest. & $18(54.5)$ & $11(78.5)$ & $29(61.7)$ \\
Neurologic manifestations & $7(21.1)$ & $2(14.2)$ & $9(19.1)$ \\
Resp. manifestations & $9(27.2)$ & $1(7.1)$ & $10(21.2)$ \\
Urogenital manifestations & $3(9.0)$ & $0(0.0)$ & $3(6.3)$ \\
\hline
\end{tabular}

Blood cultures were taken in nine patients, with positive results in four of them. Significant titers were those determined to be $>1 / 160$ in the standard tube agglutination test. Positive Wright test with titer $1 / 320$ was recorded in $26(55.3 \%)$ of patients, followed by eight $(21.1 \%)$ patients with titer $1 / 160$ and fife $(10.6 \%)$ patients with titer $1 / 1280$. The highest titer antibody level of $1 / 5120$ was observed in three $(6.3 \%)$ of patients while two $(4.2 \%)$ of patients had the titer level 1/2560. ELISA test for Brucellae was performed in all patients. Thirty-three $(70.2 \%)$ patients were IgM positive and the others 14 (29.7\%) with IgG positive. Regarding to the therapy, 45 $(95.7 \%)$ of patients were treated with streptomycin and doxycycline for the first three weeks, and then changed to doxycycline plus rifampicin for three other weeks. Two patients were commenced gentamycin and TMP/SMX for the first two weeks followed by TMP/SMX plus rifampicin. We used corticosteroid therapy in in $(17.0 \% 8)$ of patients to resolve the inflammatory symptoms.

\section{DISCUSSION}

Based on dates from the Institute of Public Health of Kosovo the incidence of human brucellosis in Kosovo during last year's is from 2.3-4.9/100 000 habitants. ${ }^{1}$ During 2011 and 2012 in Kosovo were 65 and 42 cases with brucellosis respectively. ${ }^{2}$ In this study we found that during the years 2011- 2012, 47 patients from 14 municipalities around Kosovo were admitted to our Clinic of Infectious Diseases in Pristine. Mostly of patients were male. This is significantly higher than the number of females because men are far more likely to have direct contact with livestock. This is because their work on the farm more often consists of raising and slaughtering livestock. ${ }^{1}$ In developed countries, most of the brucellosis cases occur due to occupational exposure. ${ }^{4,5}$ The majority of patients were from rural areas. The relatively high seroprevalence in village area could be explained by its location on the border where uncontrolled movement of animals may have its highest effect especially on villagers and bedouins travelling and living in close contact with animals. ${ }^{5}$

There was a known route of infection transmission; this included direct contact with livestock in and ingestion of dairy products. The two age groups most frequently represented were 11-20 and $>60$. Seroprevalence of brucellosis increased with age. ${ }^{4}$ This shows that infection occurs predominantly in males belonging to both of these age groups; young males working as shepherds and older males with an occupational exposure as farm workers. These epidemiological data are supported and from others studies. $^{4}$

Brucella infection may involve any organ or tissue in the body. Organ involvement can be assigned as focal involvement or as a complication. ${ }^{5}$ Regarding clinical manifestations the main presenting symptoms were fatigue, fever and arthralgia followed by others symptoms. Clinical studies have shown that fever is the most common feature of brucellosis, followed by osteoarticular involvement, sweating, and constitutional symptoms. ${ }^{6-14}$ Osteoarticular involvement was considered when there were inflammatory signs (heat, redness, pain, swelling, or functional disability) in any peripheral joint, or when there was unrelieved pain at rest together with radiological alterations and/or radio-nuclide uptake in any deep joint, evaluated independently by both the clinician and the radiologist. Osteoarticular involvement rates of between $58.8 \%$ and $79.5 \%$ have been reported. $., 7,15,16$ Respiratory mani- 
festations which were diagnosed by Chest X-ray were presented as a bronchopneumonia or atypical pneumonia. Neurological impairment consisted of chronic inflammatory demyelinating polyneuropathy and peroneal radiculopathy.

Brucellosis was diagnosed on the basis of serological examinations. Serology is the preferred method for the diagnosis of brucellosis when bacterial isolation is not possible, and serologic testing is widely used in the diagnosis of brucellosis. ${ }^{5}$ Blood culture is the gold standard in the diagnosis of bacterial infections, including brucellosis. ${ }^{7}$ The doxycycline plus streptomycin regimen could prove to be more effective than the doxycycline plus rifampin regimen in patients with spondylitis. ${ }^{5,15}$ One patient was treated with gentamicin and TMP/SMX for the first two weeks, before being changed to TMP/SMX plus rifampicin for the remainder of treatment. Antibiotic therapy was given for at least 6 weeks in all patients and was extended in some, depending on the patient's STAT titer and their clinical status.

In conclusion, osteoarticular symptoms were found as the most common presentation among patients with brucellosis. Development of new specific and cost-effective diagnostic algorithms for developing countries needs to be carried out, along with rapid and sensitive laboratory tests including molecular methods, to decrease morbidity in the endemic population. The most effective and preferred treatment regimen was with Streptomycin and Doxycycline for the first three weeks, and Doxycycline plus Rifampicin thereafter.

\section{REFERENCES}

1. Muçaj S, Kabashi S, Gashi S, et al. Topographic expansion of Brucellosis in Kosovo. Materia Socio Medica 2009; Vol. 21:No.2.
2. Shkodra B. Brucellosis in Gjilan Region during 2010-2012. The 1st International Conference on "Research and Education - Challenges Towards the Future" (ICRAE 2013), 24-25 May 2013.

3. Jackson R, Pite L, Kennard R, et al. Survey of the seroprevalence of brucellosis in ruminants in Kosovo. Vet Rec 2004;12;154:747-751.

4. Yumuk Z, O'Callaghan D. Brucellosis in Turkey- an overview, Int J Infect Dis 2012; 16:e228-e235.

5. Buzgan T, Karahocagil MK, Irmak H, et al. Clinical manifestations and complications in 1028 cases of brucellosis: a retrospective evaluation and review of the literature. Int $\mathrm{J}$ Infect Dis. 2010; 14:e469-e478.

6. Sauret JM, Vilissova N. Human Brucellosis. JABFP. September-October 2002; vol.15;5.

7. Franco MP1, Mulder M, Gilman RH, et al. Human brucellosis. Lancet Infect Dis 2007;7:775-786.

8. Mantur BG, Biradar MS, Bidri RC, et al. Protean clinical manifestations and diagnostic challenges of human brucellosis in adults: 16 years' experience in an endemic area. J Med Microbiol. 2006;55(Pt 7):897-903.

9. Ioannis G, Nikoleta MN, Maria E, et al. Presentation of childhood brucellosis in western Greece. Jpn J Infect Dis 2006;59:160-163.

10. Giannakopoulos I, Nikolakopoulou NM, Eliopoulou M, et al. The new global map of human brucellosis. Jpn J Infect Dis. 2006;59:160-163.

11. Black TF. Brucellosis. In: Cohen J, Powderly WG editor. Infectious diseases. 2nd ed. St. Louis: Mosby 2004;1665-1667.

12. Kassiri H, Amani H, Lotfi M. Epidemiological, laboratory, diagnostic and public health aspects of human brucellosis in western Iran. Asian Pac J Trop Biomed. 2013;3:589-594.

13. Guler S, Kokoglu OF, Ucmak H, et al. Human brucellosis in Turkey: different clinical presentations. J Infect Dev Ctries. 2014 May 14;8:581-588.

14. Pappas G, Akritidis N, Bosilkovski M, et al. Brucellosis. N Engl J Med 2005;352:2325-2336.

15. Ertek M, Yazgi $H$, Kadanali A, et al. Complications of Brucella infection among adults: an 18-year retrospective evaluation. Turk J Med Sci 2006;36:377-381.

16. Solera J, Rodríguez-Zapata M, Geijo P, et al. Doxycyclinerifampin versus doxycycline-streptomycin in treatment of human brucellosis due to Brucella melitensis. Antimicrob Agents Chemother 1995;39:2061-2067. 